\title{
Notes on the identity of Oiketicoides tedaldii (Heylaerts, 1882) (Psychidae, Oiketicinae)
}

\author{
Wilfried R. Arnscheid ${ }^{1}$, Thomas SobCzyK ${ }^{2}$, Michael Zerafa ${ }^{3}$ \\ 1 Im Ostholz 58, D-44879, Bochum, Germany \\ 2 Diesterwegstraße 28, D-02977, Hoyerswerda, Germany \\ 3 16, Triq l-imghazel, Naxxar NXR 3660, Malta \\ http://zoobank.org/2FA3A09E-9794-4580-ACBC-3463FA4E50D1
}

Received 31 October 2020; accepted 5 January 2021; published: 15 February 2021

Subject Editor: David C. Lees.

\begin{abstract}
The identity of a group of species around Oiketicoides tedaldii (Heylaerts, 1882) is discussed. The comparison of the taxa in question shows that there is considerable uncertainty about the taxonomic classification of the various described populations of Oiketicoides around the Mediterranean. The type material of $O$. tedaldii was found to be lost and therefore it is necessary to define a neotype, in order to maintain the stability of the nomenclature. The distribution of $O$. tedaldii and related taxa is discussed and morphological and molecular differences are presented.
\end{abstract}

Zusammenfassung. Die Identität einer Gruppe von Arten um Oiketicoides tedaldii (Heylaerts, 1882) wird diskutiert. Der Vergleich der in Frage kommenden Taxa zeigt, dass eine beträchtliche Unsicherheit über die taxonomische Einordnung der verschiedenen beschriebenen Populationen von Oiketicoides im Mittelmeerraum besteht. Da das Typusmaterial von $O$. tedaldii verloren gegangen ist, ist es für die Stabilität der Nomenklatur zwingend notwendig, einen Neotypus festzulegen. Die Verbreitung von O. tedaldii und verwandten Arten wird diskutiert und die morphologischen und molekularen Unterschiede werden dargestellt.

\section{Introduction}

The genus Oiketicoides Heylaerts, 1881 comprises more than 40 species described in the Palaearctic (Sobczyk 2011; Sobczyk, Arnscheid and Nuss 2013; Arnscheid and Weidlich 2017). Others are of Afrotropical and Oriental distribution. In addition to the Central Asian steppes and arid areas of the Iberian Peninsula and the Mediterranean, the mountains of North Africa are the main distribution area of the genus. From the end of the 19th to the first half of the 20th century several species of this genus have been described by different authors but most descriptions, however, are based on only one or very few specimens. The taxa were rarely illustrated, and essential characteristics like the male genitalia were not been presented. This has led to considerable confusion about taxonomy of Oiketicoides up to the present.

In this context, a group of species around Oiketicoides tedaldii (Heylaerts, 1882) deserves special consideration. The taxon was first mentioned by Heylaerts (1881), who named "tedaldii" without description. It was been made nomenclaturally available by Heylaerts himself in 1882 . 
Since that time, $O$. tedaldii has been mentioned in numerous faunistic works, but also in works on systematics and taxonomy of Psychidae in various fields. Meanwhile it is unclear whether reported specimens represent $O$. tedaldii or another species, because it is very difficult for taxonomists or other workers who are less familiar with psychids to distinguish this species from the next closest related species that shares its distribution area. In the meantime, in addition to the sparse material in collections, various molecular data are now available, so that a more clearly defined picture of the taxonomic and zoogeographic relationships concerning $O$. tedaldii is now available. We attempt to explain these relationships and to provide diagnostic information for further investigations.

\title{
Material and methods
}

\author{
Abbreviations \\ CMZ Research collection of Michael Zerafa, Naxxar, Malta \\ CTS Research collection of Thomas Sobczyk, Hoyerswerda, Germany \\ CWA Research collection of Wilfried R. Arnscheid, Bochum, Germany \\ DC Discal cell \\ ICZN International Code of Zoological Nomenclature \\ MFNB Museum für Naturkunde Berlin \\ MWM Museum Witt München \\ NMNL National Museum of Natural History Naturalis Leiden \\ SMNK Staatliches Museum für Naturkunde Karlsruhe \\ UWCP University of Wroclaw, Poland \\ ZSM Zoologische Staatssammlung München
}

\section{Indices}

FI Forewing index (maximum length from base to apex divided by the maximum width of the wings)

EI Eye index (= smallest eye distance divided by the vertical eye diameter)

Images of male genitalia (procedure as described in Arnscheid and Weidlich 2017) were taken with an Olympus OMD EM10 Mark II digital camera using an Olympus stereomicroscope with photo adapter and stacked with COMBINE ZP using Soft Stack; sharpened and denoised with Neat Image V8 and post-processed with PHOTOSCAPE V.37. Images of the adults were taken with an Olympus E1 digital camera with a 35-50 mm macro lens and a series of 12 single shots stacked with COMBINE ZP using Soft Stack; sharpened and denoised with NEAT IMAGE V8.

DNA barcode sequences in BOLD are based on a 658 base-pair long segment of the mitochondrial COI gene (cytochrome c oxidase 1). DNA samples (dried legs) were prepared and successfully processed at the Canadian Centre for DNA Barcoding (CCDB, Biodiversity Institute of Ontario, University of Guelph) to obtain DNA barcodes using the standard high-throughput protocol described in deWaard et al. (2008). Degrees of interspecific variation of DNA barcode fragments were calculated under the Kimura 2 parameter model of nucleotide substitution.

The taxonomic and collection data, voucher image, COI sequence and/or GenBank accession numbers are available for all specimens in the BOLD database (http://www.boldsystems.org). The neighbor-joining tree is based on the Kimura 2 parameter (K2P) model of nucleotide substitution 
(Kimura 1980) as recommended in the barcoding protocol (Ratnasingham and Hebert 2007, 2013) was obtained using MEGA 7.

The terminology in the description of the morphology follows Arnscheid and Weidlich (2017).

\section{Taxonomic problems}

O. tedaldii plays a key role in the clarification of which Oiketicoides species are distributed around the Mediterranean Sea. It is also the first species of the genus described from North Africa. Nevertheless, it is possible that the specimens on which the description is based belong to a mixed series. Both the Oiketicoides species from the Near East and the European and North African species have a rather localise distribution none of which known more than one continent. Looking at the details in Heylaerts' original description of 1882, it is clear that he only had two male adult specimens at his disposal. He named this new species after Luigi Failla-Tedaldi, (1853-1933 from Palermo, Sicily, Italy). However, no adult specimen from Sicily is specified. Heylaerts only mentioned several larval cases, which he had received from Zeller in 1847 from the vicinity of Anapo in Sicily, as well as further caterpillars taken by Failla-Tedaldi from Sicily, also without males, since both breedings failed. These larval cases are the only evidence for a possible occurrence of $O$. tedaldii on Sicily. The total number of syntypes is unknown, but must be larger than four. Thus, there were only larval cases from Sicily, which cannot be assigned today with absolute certainty to $O$. tedaldii since the whereabouts of the two male adults cannot be ascertained. At the end of 1881 Heylaerts received from M. Chevalier a male with the corresponding characteristic larval case from Algiers. At the same time, he mentions that this specimen corresponds "in every respect" to another specimen from Syria, which he had received from O. Staudinger to compare and describe. It can be assumed that it was from these two specimens that the description of $O$. tedaldii was made. Just as the type specimens have equal rights for primary type designation, the type localities (Sicily, Algiers, Syria) are those of the syntypes. Heylaerts further noted, however, that he compared the specimens in his possession with O. febretta (Boyer de Fonscolombe, 1835) and O. lutea (Staudinger, 1871). Here a new taxonomic problem begins. With the means and comparative collections for determination available at the time, at least $O$. tedaldii and $O$. lutea could not be separated with absolute certainty. Hence, the type material had to be studied for this paper.

The Heylaerts Collection at NMNL does not contain any of the specimens mentioned above. Six specimens (pins with one or more larval cases, some with female exuvia and label) with the numbers RMNH.INS.1283464-1283469 have been subsequently marked by an unknown person with red labels "Museum Leiden, SYNTYPE, Acanthopsyche tedaldii Heylaerts, 1882". This is a mistake. Three larval cases bear female exuviae and one of these is labelled "Heylaertsii". In the description of Amicta tedaldii Heylaerts points out that females are unknown. But Heylaerts had females of Psyche heylaertsii available to him because Millière reported on Heylaerts' observation that a female of "Psyche" heylaertsii laid 210 eggs. However, there is no evidence that the case specimens in NMNL actually belong to the syntypic series of $P$. heylaertsii. Thus there are no males and larval cases which can be safely identified as $O$. tedaldii. The syntypes of $O$. tedaldii must be considered lost.

The descriptions of $P$. heylaertsii and A. tedaldii remain of primary importance. Heylaerts does not compare Millière's description of $P$. heylaertsii with his $A$. tedaldii and lists it in contrast as a further species. It is therefore probable that Heylaerts detected differences between these two species. Later, Kirby (1892) listed $P$. heylaertsii as a subjective junior synonym of Psyche febretta 
var. lutea (Staudinger, 1871). On the other hand, Millière expressly points out that the specimens on which the description of $P$. heylaertsii is based, were also given to him by Failla-Tedaldi. They were collected in North-Eastern Sicily at an altitude of $1800 \mathrm{~m}$ in the Nebrodi Mountains, therefore, they may have been found in the summit area of Mt. Soro $(1847 \mathrm{~m})$. So, it appears there were two different consignments from Failla-Tedaldi, the first with P. heylaertsii Millière, reaching Heylaerts in 1878 or earlier. The other could have been the result of a targeted search in the Anapo Valley, which reached Heylaerts in 1881. Except for Sicily, records of P. heylaertsii from southern Italy come from Puglia, Calabria, Molise and Abruzzo (Porcelli and Parenzan 2006).

Millière described and depicted Psyche heylaertsii in 1878. However, this name has fallen into oblivion mainly because Millière's description lacks a geographic origin of this taxon. However, in a further publication (Millière 1881), he left no doubt that as already mentioned he referred to specimens from the Nebrodi Mountains in Sicily. Kirby (1892) synonymized P. heylaertsii and $P$. sera in his catalogue, but obviously he did not know the correct year of the description of $P$. heylaertsii and therefore he refers erroneously to Millière's work of 1881. In his monograph Heylaerts (1881) listed among the genus Amicta the taxon tedaldii as a separate species besides Psyche heylaertsii Millière, 1878. Psyche sera Wiskott, 1880 is listed as a synonym of Psyche heylaertsii. Thus, it is not $P$. sera, as Kirby states, but $P$. heylaertsii, that is the older and therefore the valid name for the taxon in question here.

During the studies for this paper, we examined in the Staudinger Collection at MFNB Oiketicoides specimens that might be considered as syntypes of $O$. tedaldii. One of these specimens is labelled "lutea var. timona Heyl.". No taxon bearing this name has ever been described. In any case, the name "timona" indicates an origin from Syria, because it is the name of a deacon of the ancient Christian community in the 1st century, who later lived in Aleppo. As already shown, Syria may be a possible locality for $O$. tedaldii. But unfortunately, we found this and another questionable specimen in the Staudinger collection which is labelled "lutea var." both belonging to another species, probably O. jordana (Staudinger, 1899).

Despite intensive searches, the syntypes of $O$. tedaldii could not be found and they must be considered as lost. It can be recognised without doubt that Heylaerts knew two different species of Oiketicoides from Sicily, which according to current understanding are $O$. tedaldii and $O$. lutea (respectively; Psyche sera and Psyche heylaertsii being probably synonyms of the latter). Even today this situation has not changed. Furthermore, the frequency of the cases of $O$. tedaldii at several locations described by Heylaerts allows the conclusion that it was and is a widespread species. Altogether it was impossible to verify true $O$. tedaldii, neither from the Near East nor from North Africa. The exclusion of $O$. lutea and the presence of another Oiketicoides species in Sicily allows at least the identity of the Sicilian species to be established with respect to $O$. tedaldii. This is also the case with the two Oiketicoides species occurring on Malta. One of these species could be identified as $O$. tedaldii by its morphological characters, larval cases and DNA barcode (Arnscheid, Weidlich and Zerafa, unpubl.). Such a reconstruction is not possible for the North African and Near Eastern species due to their much higher diversity (Sobczyk and Arnscheid, in prep.) and low proportion of undescribed species.

\section{Molecular analysis of the Oiketicoides species mentioned here}

In the BOLD, the database of the Canadian Centre for DNA Barcoding (CCDB) as well as on the GenBank (https://www.ncbi.nlm.nih.gov/genbank/), several publicly accessible samples are 
Table 1. Pairwise DNA barcode divergences between two Oiketicoides taxa from South Europe.

\begin{tabular}{ccccccc}
\hline Species & Sequence No. & Locality & \multicolumn{3}{c}{ Pairwise distance (\%) } \\
\hline Oiketicoides tedaldii & GBGL32882-19 & Malta & & & & \\
& GBGL32883-19 & Malta & 0.00 & & & \\
Oiketicoides lutea & GWORU342-10 & Cosenza, Italy & 13.8 & 13.8 & & \\
& GWORZ165-10 & Cosenza, Italy & 13.6 & 13.6 & 0.3 & 0.2 \\
& PSYCH086-11 & Zagoria, Greece & 13.7 & 13.7 & 0.2 & 0.2 \\
\hline
\end{tabular}
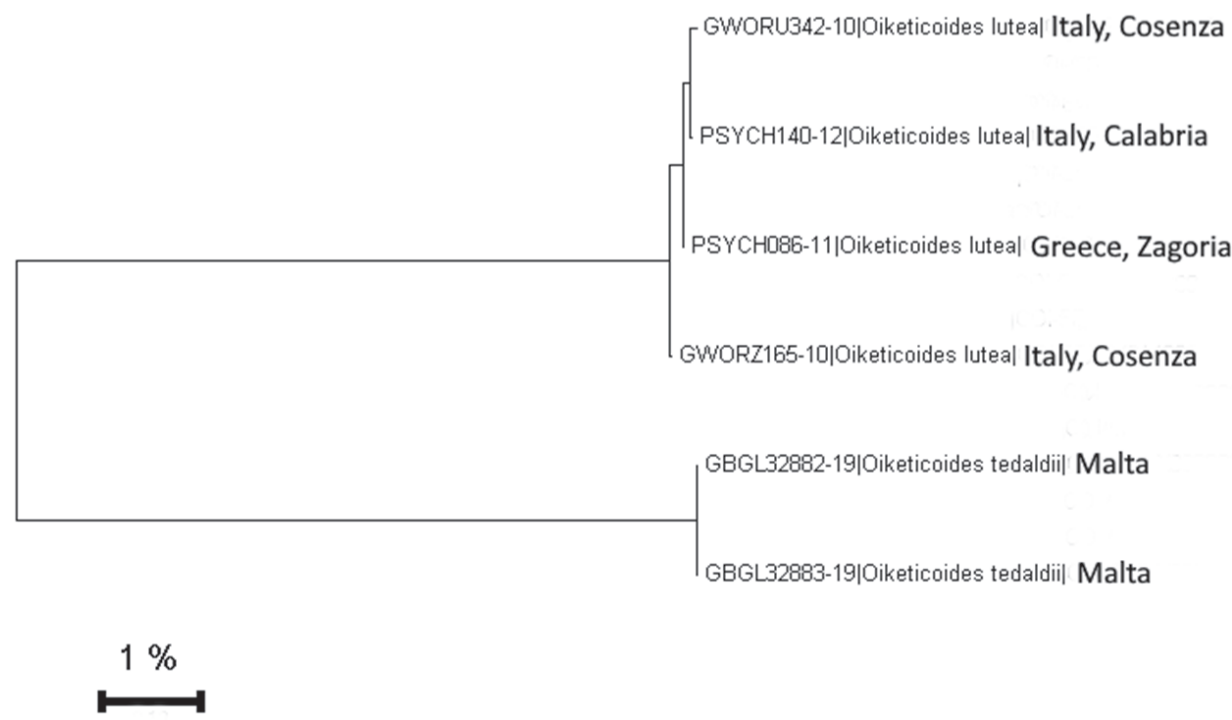

Figure 1. Neighbor-joining tree of the Oiketicoides species from South Europe.

available, which belong to the taxa $O$. tedaldii and $O$. lutea. The samples are generated from the following Barcode Index Numbers (BIN) BOLD:AAM0038 (GWORZ165-10), BOLD:AAP3634 (GWORU342-10), BOLD:ABU7325 (PSYCH086-11). The Sequence No. PSYCH140-12 has no BIN. The Sequence Nos. GBGL32882-19 and GBGL32883-19 were generated from GenBank Access Numbers KX399366 and KX399372. This shows that the infra-specific divergence is a maximum of $0.3 \%$ or zero whichever is applicable in $O$. lutea but negligible in $O$. tedaldii. In contrast, the interspecific divergence between $O$. lutea and $O$. tedaldii is $13.3-13.8 \%$ (Tab. 1, Fig. 1). This also shows, that in South Europe two distinct Oiketicoides species exist, from which one must be the previously enigmatic $O$. tedaldii.

\section{The identity and distribution of $O$. tedaldii (Heylarts, 1882)}

Considering the taxa of the genus Oiketicoides in the western Mediterranean area, starting from the presumed distribution area of $O$. tedaldii, three taxa are questionable according to previous knowledge. One of them is O. febretta. However, a confusion with O. tedaldii (sensu lato) can be excluded, as $O$. febretta is an easily recognisable species, which was certainly understood correctly in the past. Thus the taxa O. lutea and Psyche sera, which some authors considered as separate species, are preserved remain, but according to Heylaerts (1881) Psyche sera is a junior synonym for Psyche heylaertsii and thus, according to Kirby (1892) to O. lutea. 
Wiskott's (1880) description of $P$. sera is very short: “ $O$, Alis cinereis; capillis inferiore capitis parte, antennis, margine anteriore alarum anticarum, ciliis nigro-cinereis; capillis superiore capitis parte, thorace, abdomine, pedibus, cano-flavescendibus. Lutea propinqua, sed minor, colore obscuriore, antennis, tenuioribus, alis magis rotundatis, Esp. $21 \mathrm{~mm}$. : Ignota. Patria: Sicilia (Litus septentrionale).“

Translation: " $\curvearrowright$, Wings grey; the lower part of the head, antennae and the edge of the forewings darker black-grey, the upper part of the head, the thorax and the feet are greyish yellow-brown. Closely related to $O$. lutea Stgr., but smaller, darker colours and more rounded, thin wings, span $21 \mathrm{~mm}$. o : unknown. Region: Sicily."

The description partly correlates with both Oiketicoides species occurring on the island of Sicily. Especially the statement that $O$. lutea has rounder wings does not allow to exclude with absolute certainty that Wiskott's specimen might not have been $O$. tedaldii. The surprising recovery of the only syntype of P. sera in the Wiskott Collection in UWCP, however, shows that this taxon is without question the one also known as "sera" in today's sense.

Looking closer to the distribution areas of these three taxa known from literature shows the following result: The type locality of $O$. lutea is Mt. Veluchi in Greece. The species is also mentioned from Albania, Bulgaria, Crete, Sicily, Italy, North-Macedonia, Croatia and Serbia. Furthermore, Armenia, Georgia, Turkey, Iraq, Lebanon, Palestine, Syria and Russia are mentioned, however, the latter records will most likely be confused with other species. Concrete evidence of distribution is only available from the wider Balkan region.

Since it was not possible to find syntypes of $O$. tedaldii, and in regard to the taxonomic problems outlined above, there is an urgent need for the stability of the nomenclature to define a neotype. The determination of a neotype is in accordance with Art. 75 of the ICZN (Kraus 2000). For this purpose, the diagnostic characteristics of the specimens considered for this taxon are compared below. One indication of Heylaerts (1882) in his description can be considered as particularly important: the larval cases of the species he describes are characteristically covered with fragments of shells of small molluscs. We therefore assume that the specimens with the corresponding larval cases now available to us represented the taxon that Heylaerts described in 1882 as $O$. tedaldii. Oberthür (1909) pictured a male, female, and such a typical larval case as O. tedaldii from Algeria (Khenchala). Last but not least, due to the fact that no certain specimen (with the characteristic larval case) of $O$. tedaldii from North Africa nor from the Near East is available, we select a specimen with a larval case from Sicily for neotype:

\section{Oiketicoides tedaldii (Heylaerts, 1882)}

Figs 2(1), 4

The neotype is labelled as follows:

1) Sicilia, Ficuzza, 16.ix., Krüger Geo. C. 2) det. Dr. Wehrli A. tedaldii Heyl. 3) Oiketicoides tedaldii Heyl., det. Arnscheid, Präp. 4077 4) Slg. Daniel. 5) red label: NEOTYPUS, Oiketicoides tedaldii (Heylaerts, 1882).

The neotype is deposited in the MWM.

Description. Head dorsolaterally long, yellowish brown, hair-shaped scaled. Eyes ovoid, AI: 0.54. Antennae bipectinate with 29 pecten. Pecten ciliated and scaled. Antennae length $5 \mathrm{~mm}$. Wings light brown, forewings costa straight, apex roundish, termen oblique. Underside equally coloured. Fringes yellowish brown with a whitish gloss distally. Wingspan $22 \mathrm{~mm}$, wing length $9 \mathrm{~mm}$, wing 

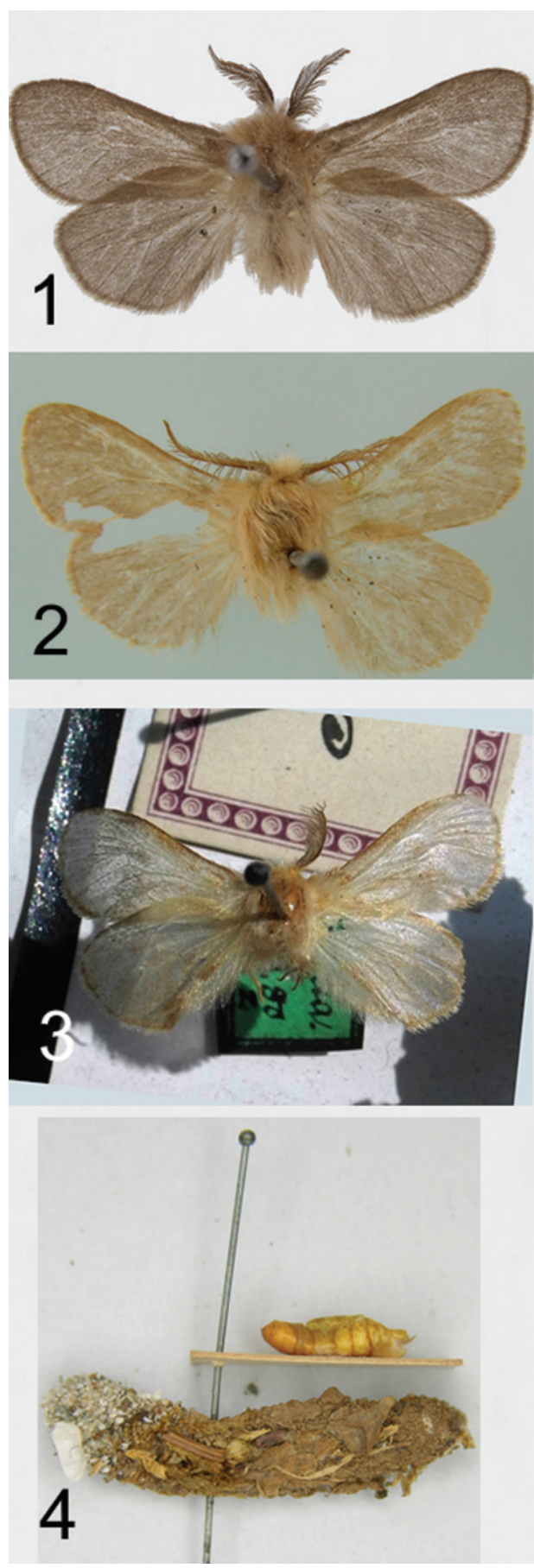
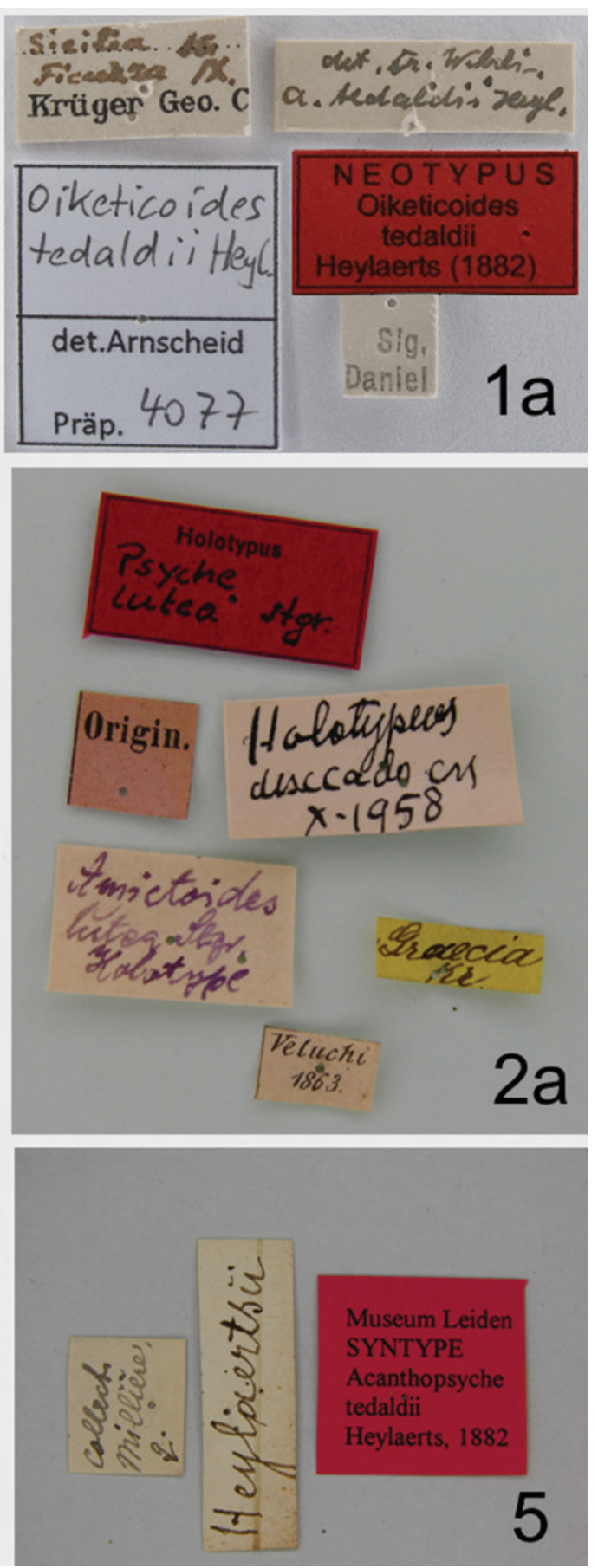

Figure 2. 1, 1a. Neotype of Oiketicoides tedaldii (Heylaerts, 1882) and labels in MWM. 2, 2a. Holotype and labels of Psyche lutea Staudinge (1871) in MFNB. 3. Holotype of Amicta sera Wiskott, 1880 in UWCP. 4, 5. Case and labels of Psyche heylaertsii Millière, 1878, erroneously labelled as syntype of Acanthopsyche tedaldii Heylaerts, 1882 (NMNL). 
width $5 \mathrm{~mm}$, FI: 1.8. Scales short, unstalked or short stalked. Mostly with two dentations, partially with 3 dentations (classes 1-2, after Sauter 1956). Fringes yellowish brown with a whitish gloss distally Fringe scales with 3-5 dentations. Forewing venation with 10 veins from discal cell. Discal cell divided, veins $\mathrm{r} 3+\mathrm{r} 4$ stalked of $1 / 3$ length. Hindwing venation with 7 veins, $\mathrm{m} 1$ and $\mathrm{m} 2$ short stalked. Genitalia (slide 4077 Arnscheid): Tegumen and vinculum fused. Tegumen ovoid, folded laterally. Valva short and broad, of tegumen length. Distinctly indented above vinculum laterally. Vinculum stretched, triangle shaped. Clasper of sacculus short and slender, covered distally with 6 short spines. Saccus long and stretched, of tegumen length. Phallus very long, thick, weakly curved, vesica without cornuti but with a broad pointed process laterally.

The confirmed distribution of $O$. tedaldii with both specimens and cases is thus from Italy: Sicily [Ficuzza, Madonie, Caltanisetta], Malta [Imtaћleb, Bingemma, Naxxar Gap, Gharghur: Ġebel San Pietru, Mellieha]. As has already been shown, there are hints that this species also occurs in Algeria and Tunisia (Fig. 8a, b).

\section{Redescription of the male morphology of $\boldsymbol{O}$. tedaldii (Heylaerts, 1882)}

Figs $3(1-3), 4,6(1-4), 7(1,4)$

Head dorsolaterally long, yellowish brown, hair-shaped scaled. Eyes ovoid, AI: 0.54-0.55. Antennae bipectinate with 29-30 pecten. Pecten long ciliated. Antennae length $5 \mathrm{~mm}$. Wings light brown, forewings costa straight, apex roundish, termen oblique. Underside equally coloured. Wingspan 20-24.5 mm. Forewing with 10 veins from discal cell, r3 $+\mathrm{r} 4$ and $\mathrm{m} 2+\mathrm{m} 3$ stalked. Junction of vein $\mathrm{m} 1$ to DC complete. Hindwing with 7 veins from DC. Veins $\mathrm{m} 2+\mathrm{m} 3$ stalked. Sometimes with small, intercalated cells at the base with the DC, FI: 1.8-1.9. Scales short, unstalked or short stalked. Mostly with two dentations, partially with 3 dentations (classes 1-2, after Sauter, 1956). Fringe scales whitish, light brown basally, distinctly glossy, with 3-5 dentations. Less indented than in O. lutea. Genitalia: Tegumen and vinculum fused. Tegumen ovoid, folded laterally. Valva short and broad, of tegumen length. Distinctly indented above vinculum laterally. Vinculum stretched, triangle shaped. Clasper of sacculus short and slender, covered distally with 6 short spines. Saccus long and stretched, of tegumen length. Phallus very long, thick, weakly curved, vesica without cornuti but with a broad pointed process laterally. Larval Case: Male length 20-25 mm, diameter 5.5-6 mm. Cylindrical, slightly curved with circular cross section, covered with fine particles of soil and bits of broken snail shells, twigs, mineral debris and dry plants matter. Front opening is covered with smaller plant material and soil.

\section{Redescription of the male morphology of O. lutea (Staudinger, 1871)}

Figs 3 (4-10), 5, 6 (5-6), 7 (2, 3, 5, 6)

Head dorsolaterally long, brown hair-shaped scaled. Eyes ovoid, AI: 0.67-0.68. Antennae bipectinate with 33-34 pecten. Pecten long ciliated. Antennae length $5 \mathrm{~mm}$. Wings light brown, forewings costa mostly slightly concave in the basal half, apex roundish, termen oblique or roundish. Underside equally coloured. Wingspan $21-25.5 \mathrm{~mm}$. Forewing with 10 veins from discal cell, r $3+\mathrm{r} 4$ and $\mathrm{m} 2+\mathrm{m} 3$ stalked, rarely from one-point rising or completely divided. Junction of vein $\mathrm{m} 1$ to DC complete. Hindwing with 7 veins from discal cell. Veins $\mathrm{m} 2+\mathrm{m} 3$ stalked. Small, intercalated cells at the base of the DC absent, FI: 1.82-1.93 (the southern populations of Greece and Italy mainland and 


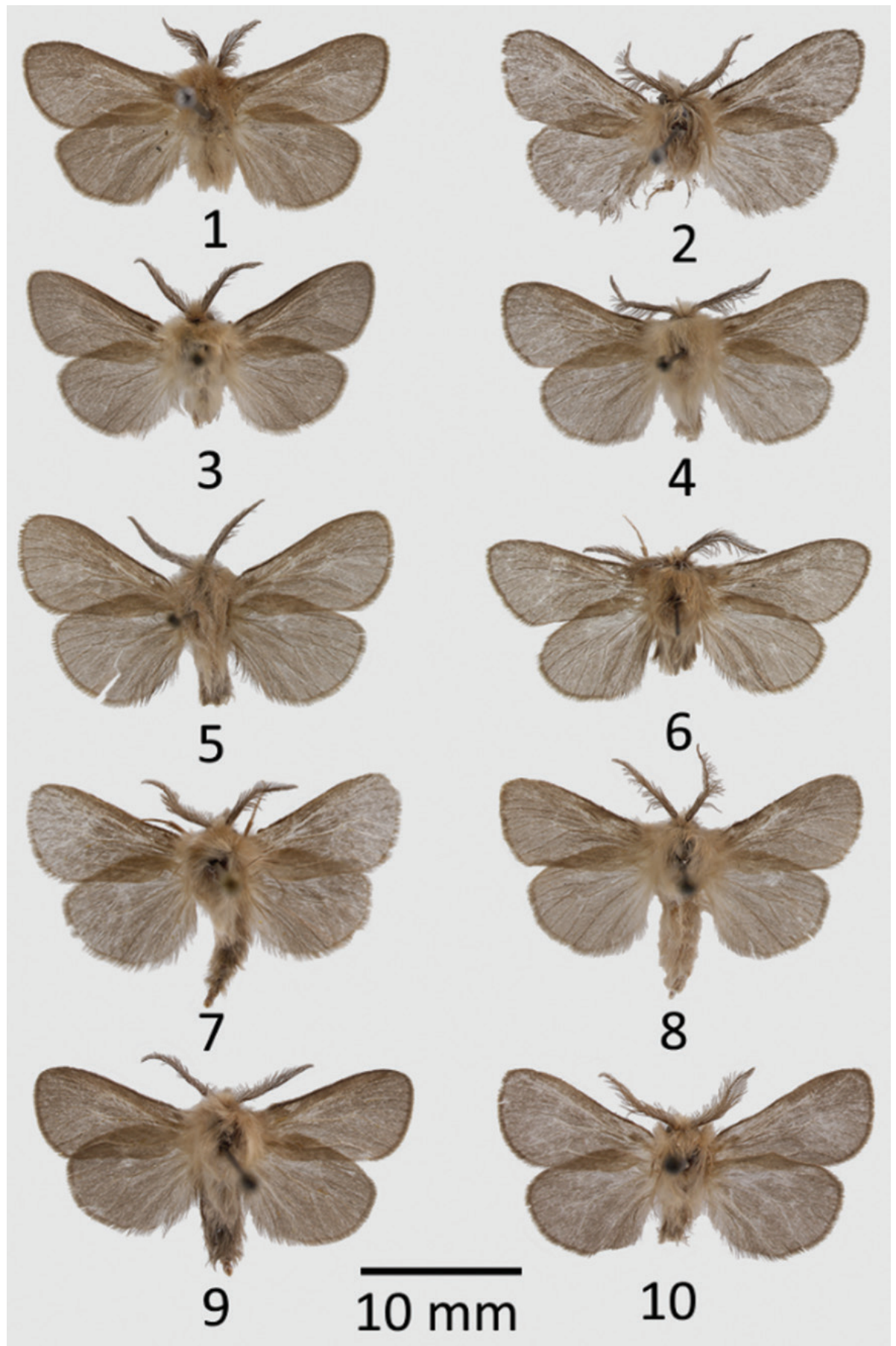

Figure 3. Males of Oiketicoides tedaldii and O. lutea from Europe. 1. O. tedaldii, neotype, Italy, Sicily, Ficuzza. 2. O. tedaldii, Italy, Sicily, Madonia. 3. O. tedaldii, Malta. 4. O. lutea Italy, Sicily, Madonia. 5. O. lutea, Italy, mainland, Sila mts. Spaviera. 6. O. lutea Italy, Taranto, San Paolo. 7. O. lutea, Italy, Sicily, Agrigento. 8. O. lutea Italy, Caltanisetta, Barburra. 9. O. lutea, North Macedonia, Lake Ohrid. 10. O. lutea, Greece, Zachlarou. 

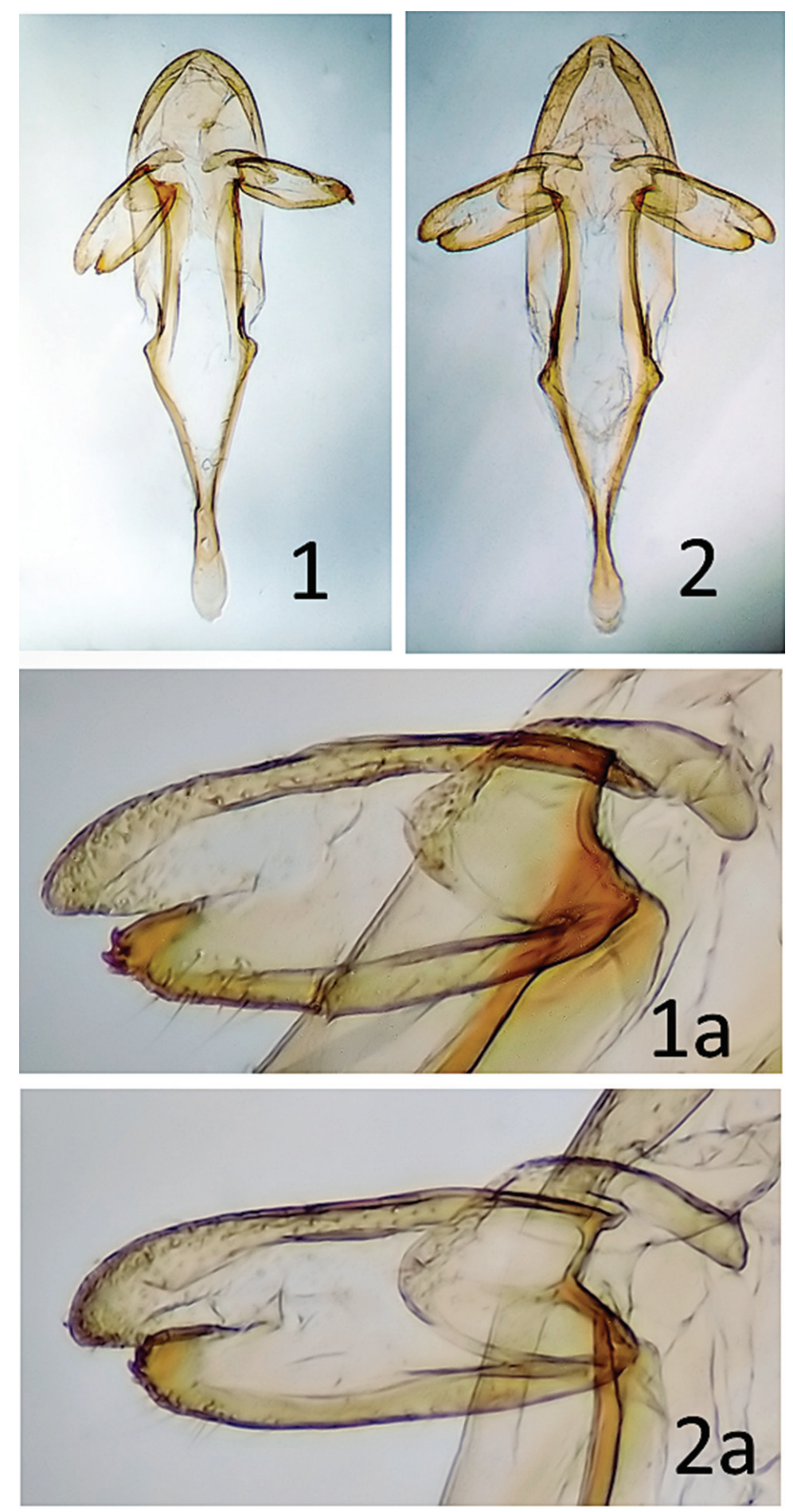

Figure 4. Male genitalia of Oiketicoides tedaldii (Heylaerts, 1882). 1, 1a. Neotype, Italy, Sicily, Ficuzza, (genital slide 4077, CWA). 2, 2a. Italy, Sicily, Caltanisetta (genital slide 4084, CWA). 

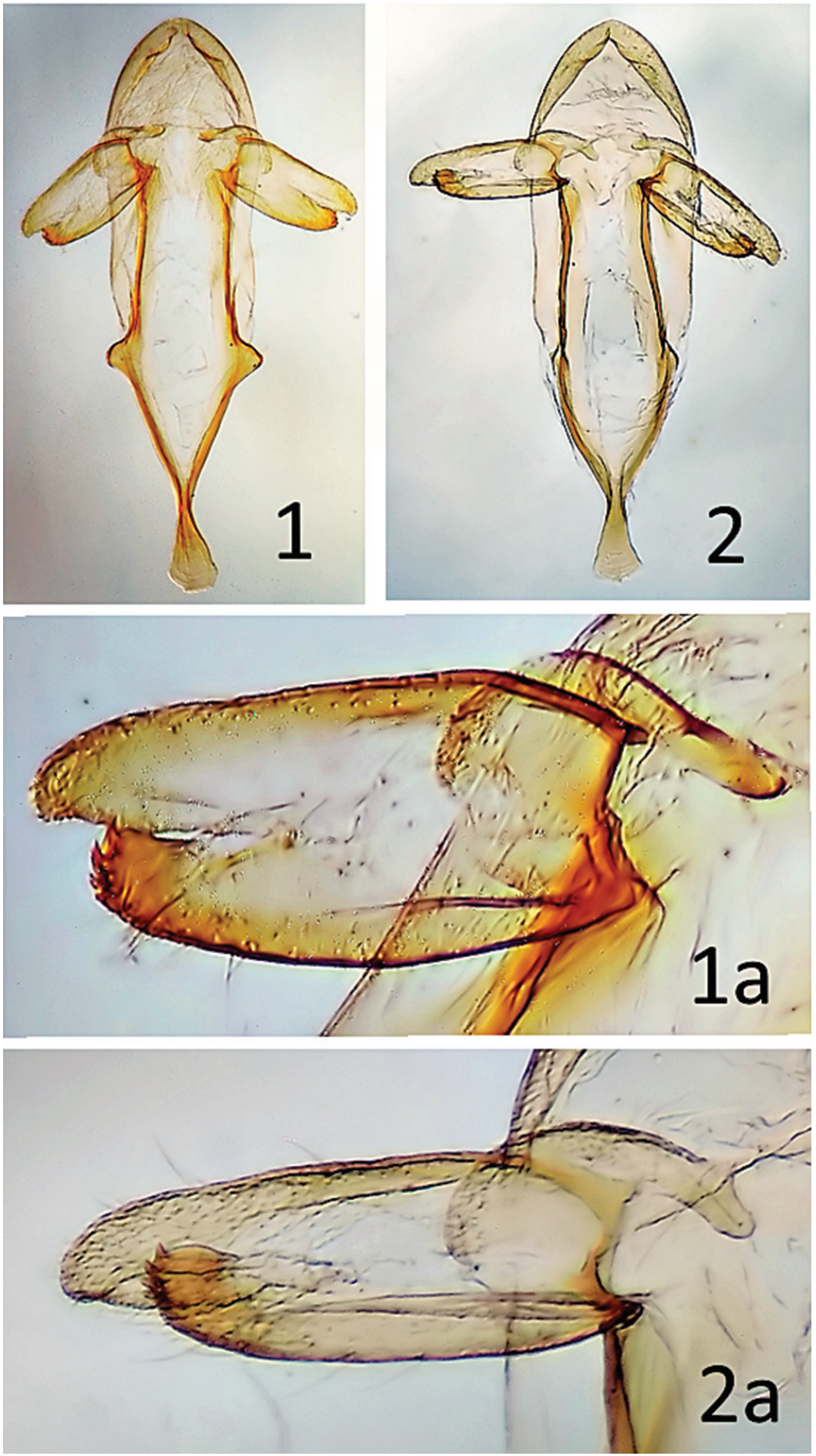

Figure 5. Male genitalia of Oiketicoides lutea (Staudinger, 1871). 1, 1a. Italy, Sicily, Madonie (genital slide 4079, CWA). 2, 2a. Italy, Sicily. 


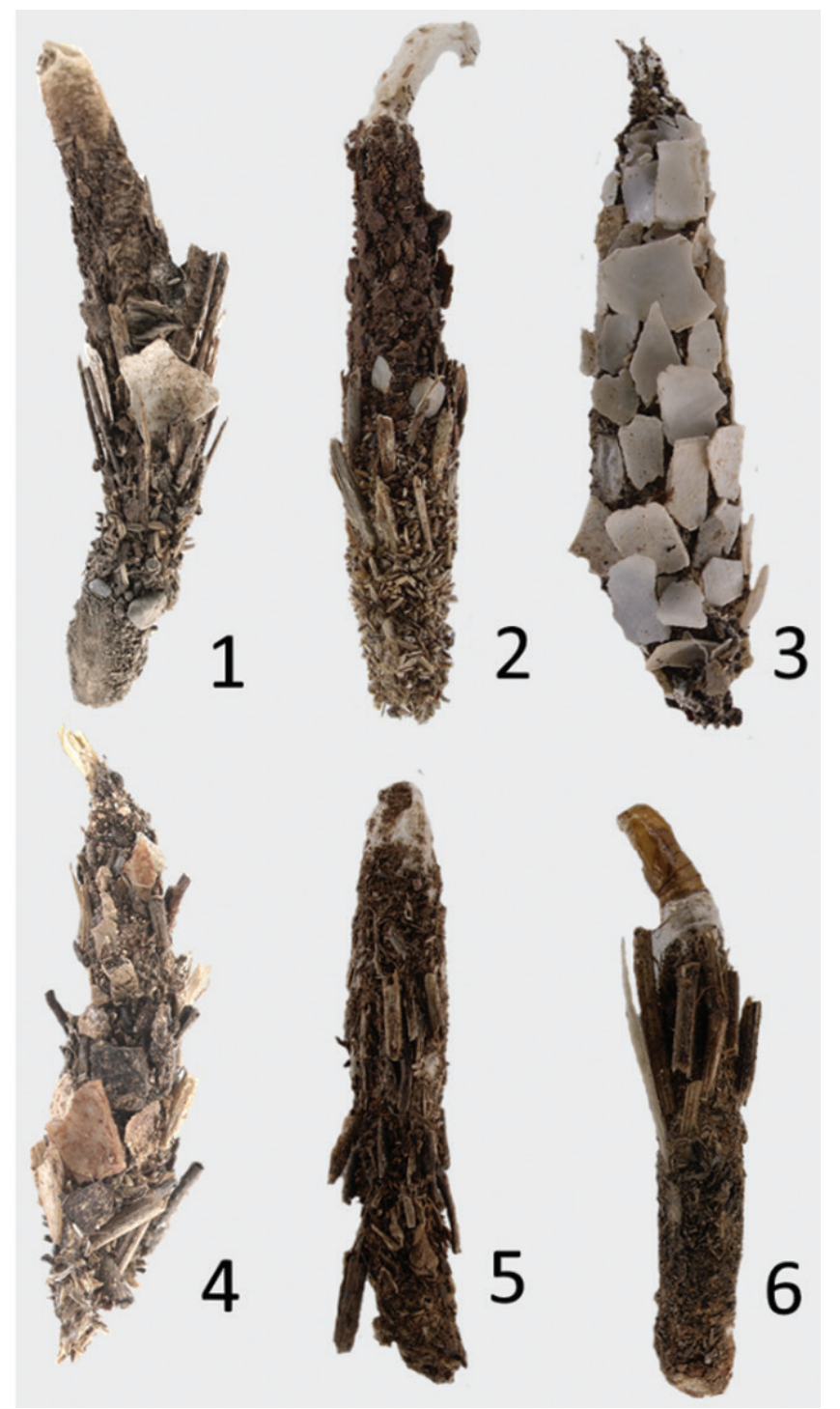

Figure 6. The larval cases of Oiketicoides tedaldii (Heylaerts, 1882) and O. lutea (Staudinger, 1871). O. tedaldii: 1, 2. Italy, Sicily, 3. Tunisia, 4. Malta. O.lutea: 5, 6. Sicily.

Sicily, $\mathrm{n}=17$ ) and 2.14 (Populations of northern Balkans, $\mathrm{n}=15$ ). Scales elongated, lanceolate, unstalked or short stalked. Mostly with 1-2 dentations (classes 1-2, after Sauter 1956). Fringe scales whitish, light brown basally, distinctly glossy, with 3-5 dentations, deeper indented than in $O$. tedaldii. Male Genitalia: Tegumen and vinculum fused. Tegumen ovoid, folded laterally. Valva short and broad, of tegumen length. Not or only slightly indented above vinculum laterally, with distinctly visible or intimated triangle-shape projects laterally. Vinculum broad, triangle shaped or slightly rounded laterally. Clasper of sacculus short and mostly broader than in $O$. tedaldii, covered distally 

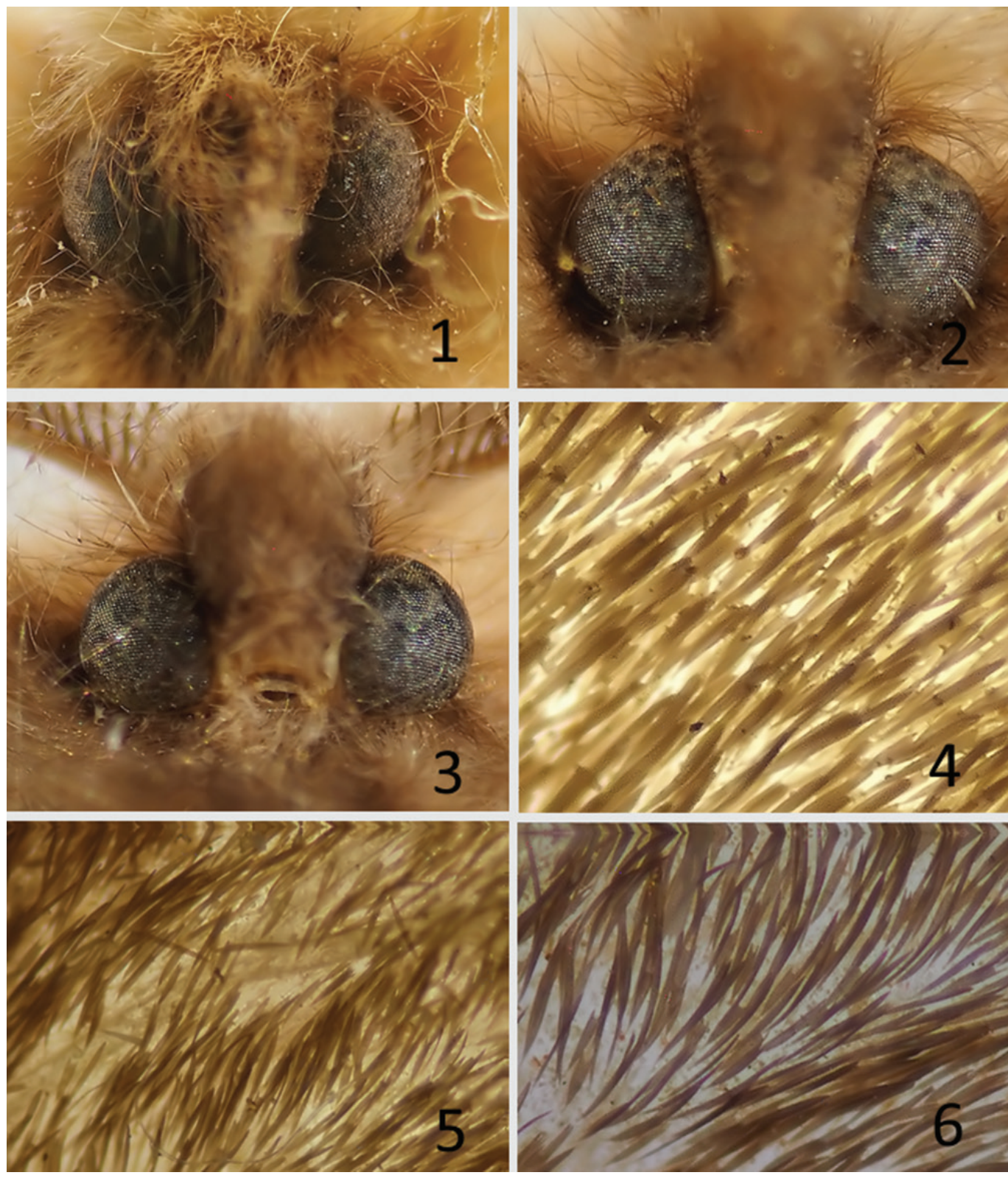

Figure 7. Eye area and forewing scales of the $O$. tedaldii-species group. 1, 4. $O$. tedaldii, neotype, Italy, Sicily. 2, 5. O. lutea, Italy, Sicily, Madonie. 3, 6. O. lutea, North-Macedonia, Lake Ohrid.

with 5-6 longer spines. Saccus short and widened and rounded distally, fishtail-shaped. Phallus very long, thick, weakly curved, vesica without cornuti but with a broad pointed process laterally. Larval Case: Length 19-25 mm, diameter 5-6 mm. Cylindrical, covered with fine particles of soil, twigs, mineral debris and dry plants matter. Front opening is covered with smaller plant material. 

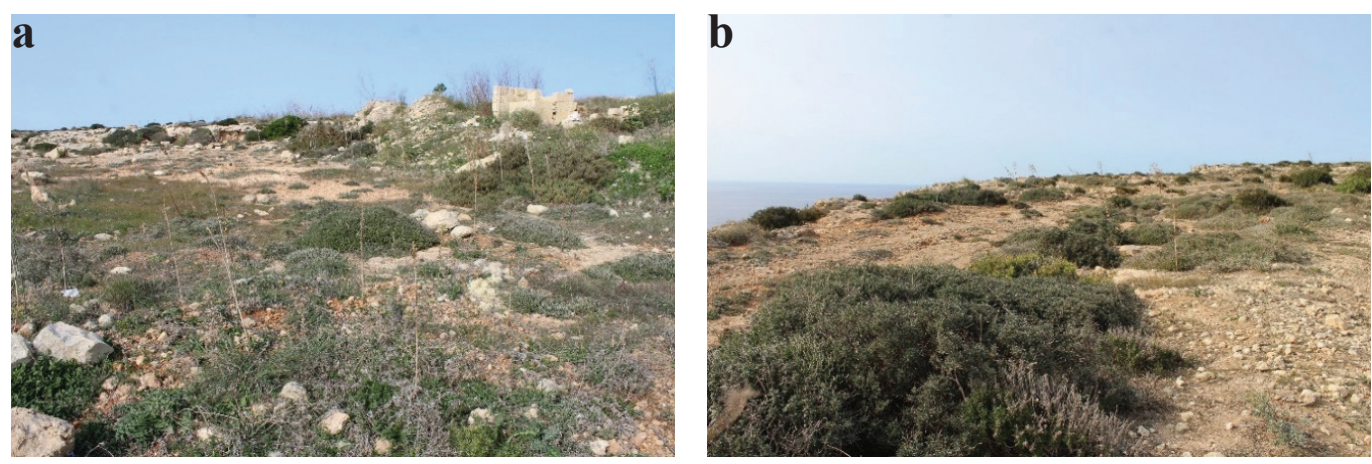

Figure 8. a, b. Habitat of $O$. tedaldii, Malta, Imtahleb, 184 m. Photos: M. Zerafa

\section{Acknowledgements}

Without the help of our friends and colleagues this work would not have been possible. Thomas J. Witt ( $\dagger$ ) generously enabled us to work on the material of his extensive collection for many years. The same applies to Robert Trusch and Michael Falkenberg (both SMNK) as well as Wolfram Mey, Viola Richter and Théo Léger (all MFNB). Furthermore, we would like to thank Peter Hättenschwiler (Uster), Marek Wanat (UWCP) and Ana Nahirnic (Sofia) for their valuable help in different ways. Our special thanks goes to Rob de Vos (NMNL) for his support while searching for the type material of $O$. tedaldii. We also thank one reviewer for helpful discussion and careful review of the manuscript.

\section{References}

Arnscheid WR, Weidlich M (2017) Psychidae. In: Karsholt O, Mutanen M, Nuss M (Eds) Microlepidoptera of Europe (Vol. VIII). Brill, Boston and Leiden, 423 pp.

Boyer de Fonscolombe LJH (1835) Description de la Psyche febretta, nouvelle espèce de Bombycites. Annales de la Société entomologiques de France 4: 107-110.

DeWaard JR, Ivanova NV, Hajibabaei M, Hebert PDN (2008) Assembling DNA Barcodes: Analytical Protocols. In: Martin CC (Ed.) Methods in Molecular Biology: Environmental Genomics. Humana Press Inc., Totowa, 364 pp. https://doi.org/10.1007/978-1-59745-548-0_15

Heylaerts FJM (1881) Essai d'une monographie des Psychides de la faune européenne. Annales de la Société entomologiques de Belgique 25: 2-73.

Heylaerts FJM (1882) Descriptions de deux nouvelles espèces de Psychides. Annales de la Société entomologiques de Belgique 26: 139-151.

Kimura M (1980) A simple method for estimating evolutionary rates of base substitutions through comparative studies of nucleotide sequences. Journal of Molecular Evolution 16: 111-120. https://doi.org/10.1007/ BF01731581

Kirby W (1892) A synonymic catalogue of lepidoptera Heterocera (Moths). 1. Sphinges and Bombyces. London, Parternoster Row, 952 pp.

Kraus O (2000) Internationale Regeln für die Zoologische Nomenklatur. Vierte Auflage. Offizieller deutscher Text. Abhandlungen des Naturwissenschaftlichen Vereins Hamburg (NF) 34: 1-232.

Millière MP (1881) Lépidoptérologie 1(7): 1-22.

Oberthür C (1909) Explication des planches. Études de Lépidoptérologie Comparée 3: 405-415.

Ratnasingham S, Hebert PDN (2007) BOLD: The Barcode of Life Data System (http://www.barcodinglife.org). Molecular Ecological Notes 7: 355-364. https://doi.org/10.1111/j.1471-8286.2007.01678.x 
Ratnasingham S, Hebert PDN (2013) A DNA-Based Registry for All Animal Species: The Barcode Index Number (BIN) System. PLoS ONE 8(7): e66213. https://doi.org/10.1371/journal.pone.0066213

Sobczyk T (2011) Psychidae (Lepidoptera). In: Nuss M (Ed.) World Catalogue of Insects (Vol. 10). Apollo Books, Stenstrup, 467 pp.

Sobczyk T, Arnscheid WR, Nuss M (2014) Taxonomische Revision von Oiketicoides Heylaerts, 1881 von der Iberischen Halbinsel (Lepidoptera: Psychidae, Oiketicinae). Entomologische Zeitschrift 124(4): 215-226. Wiskott M (1880) Psyche sera, n. sp. (mihi). Entomologische Nachrichten 6: 242. 